\title{
Impact of Climate Change on Population Dynamics and Herbicide Resistance in Kochia (Bassia scoparia (L.) A. J. Scott)
}

\author{
Jinyi Chen ${ }^{1} \mathbb{C}$, Erin Burns ${ }^{1}$, Margaret Fleming ${ }^{2}$ and Eric Patterson ${ }^{1, *(\mathbb{C}}$ \\ 1 Department of Plant, Soil and Microbial Sciences, Michigan State University, East Lansing, MI 48824, USA; \\ chenj160@msu.edu (J.C.); burnser5@msu.edu (E.B.) \\ 2 Department of Plant Biology, Michigan State University, East Lansing, MI 48824, USA; flemi221@msu.edu \\ * Correspondence: patte543@msu.edu; Tel.: +1-517-353-0467
}

Received: 8 October 2020; Accepted: 29 October 2020; Published: 3 November 2020

\begin{abstract}
Climate change has greatly impacted agronomy. Climate forecasts for the coming years predict increases in global temperature, carbon dioxide concentration, and extreme weather events. These changes will continue to influence agricultural production by altering abiotic stress on plants, including crops and weeds. Kochia, one of the most common weeds in North America, is a C4 plant exceptional for its drought tolerance. Kochia has also demonstrated rapid adaption and evolution to the abiotic stress of herbicide application, particularly glyphosate. Abiotic stresses from both climate change and herbicides impact the distribution and expansion of kochia. Being aware of the features and properties of kochia, especially those resulting from herbicide resistance, will help anticipate how kochia responds or migrates under future climate change, and help create proper strategies for kochia weed management.
\end{abstract}

Keywords: kochia; climate change; weeds; herbicide resistance

\section{Introduction}

Global climate change predictions forecast changes in climate conditions that are quintessential for successful crop production and weed management. Climate change predictions include elevated temperature, increase in carbon dioxide $\left(\mathrm{CO}_{2}\right)$ concentration, and more frequent erratic precipitation events [1]. Climate change is disastrous for threatened species living in a narrow niche [2-4]. However, disruptions due to climate change can be exploited by pests, potentially expanding their range and ecological niche. This will especially be the case if crop cultivars optimized to the prior climate regime are maladapted to their new growing environment and are left less competitive [5-7].

Weeds are noxious pests that are highly competitive, adaptive, and able to withstand multiple stressors, including drought, waterlogging, elevated temperature, and increased $\mathrm{CO}_{2}[6,8,9]$. Kochia (Bassia scoparia (L.) A. J. Scott) is a diploid $(2 n=18)$ weed species and belongs to the Chenopodiaceae family. Kochia is native to Eastern Europe and Asia, and is now one of the most common weed species in North American Great Plains [10]. Kochia competes with multiple crops (sugar beet, corn, etc.), causing significant crop yield reduction [11-15]. It is especially well suited to arid and semi-arid climes, and invades a myriad of environments including cropland, rangeland, gardens, roadsides, and almost any disturbed ground. Infestations range in latitude from Mexico to Canada and currently exist in forty-three of the contiguous United States (United States Department of Agriculture Bassia scoparia factsheet). Kochia possesses physiological traits that may help it thrive during climate change. In particular, kochia's natural abiotic stress tolerance is deeply associated with a strong artificial abiotic stress tolerance, namely, herbicide resistance. 
In this review, we will discuss how kochia, especially herbicide-resistant kochia populations, may respond to a changing climate. Factors considered here include changes in abiotic factors such as temperature, $\mathrm{CO}_{2}$ concentration, and precipitation, as well as kochia-specific traits such as photosynthetic efficiency, herbicide resistance and fitness penalties, genomics and genetic diversity, and previous work looking at population expansion.

\section{Abiotic Stress in Kochia}

\subsection{Temperature}

It is predicted that the mean global temperature will continue to increase over the 21st century with a corresponding increase in the frequency, duration, and magnitude of hot extremes [16]. Increasing temperature can greatly impact plant growth and phenology [17]. Many plant species can tolerate higher temperatures during vegetative growth stages, but not during reproductive growth stages [17].

Crop-weed communities shift under different temperatures, due to factors in the agroecosystem and weed physiological traits. As temperature increases, crop planting dates are likely to shift toward early spring, depending on spring precipitation [18]. Weed communities are also predicted to alter as planting dates become earlier. Additionally, as seed germination timing is influenced by temperature, elevated temperatures in early spring may lead to shifts in weed emergence and overall phenology such as plant height, branching, leaf emergence, etc. [19].

For kochia, a variety of population-specific germination patterns (i.e., emergence rate and timing) have been identified [20]. The range expansion of kochia has already been documented in many regions of North America. Studies in Canada noted that over the past 40 years the frost-free growing season has increased by four days. What appears to be a relatively small increase in the growing season coincided with first reports of kochia invading the more northern regions of Canada (Manitoba, Saskatchewan, and Alberta) [21]. More specifically, climate models project that kochia's range in the United States will expand eastward into the Midwest and Atlantic regions with temperature increases of $1-3{ }^{\circ} \mathrm{C}$ [21].

Although mean global temperatures are predicted to increase, there may also be an increase in sudden freezing events in certain areas [22]. Despite being a C4 plant, kochia is extremely cold-tolerant and it handles the sudden freezes in early spring of the high-plains with ease. Kochia is among the first weeds to germinate, often germinating under snow. Its cold tolerance may be due, in part, to its "kochioid" Kranz anatomy, which is shared with several other halophytes in the Camphorosmeae [23]. Cold-tolerant kochia is also expected to migrate and expand its range northward, because increasing global temperature will shrink the size of the cold region toward polar areas.

\subsection{Carbon Dioxide $\left(\mathrm{CO}_{2}\right)$}

Atmospheric $\mathrm{CO}_{2}$ concentration is predicted to increase under climate change scenarios. According to www.climate.gov, since 1972, atmospheric $\mathrm{CO}_{2}$ concentrations have increased from $324 \mathrm{ppm}$ to $414 \mathrm{ppm}$, with an average increase of $2.3 \mathrm{ppm}$ per year [24]. Increasing $\mathrm{CO}_{2}$ will directly impact photosynthesis, transpiration, and respiration, but the direction of the response is dependent on the types of photosynthesis. For $\mathrm{C} 4$ plants, increasing $\mathrm{CO}_{2}$ will not affect the photosynthetic rate, due to their physiology that concentrates $\mathrm{CO}_{2}$ levels around Rubisco [25]. For C3 plants, current levels of atmospheric $\mathrm{CO}_{2}$ do not saturate the Rubisco enzyme. Therefore, elevated $\mathrm{CO}_{2}$ will stimulate $\mathrm{C} 3$ photosynthesis by reducing the loss of $\mathrm{CO}_{2}$ through photorespiration and increasing the concentration gradient of $\mathrm{CO}_{2}$ from air to leaf [25-27]. For crassulacean acid metabolism (CAM) plants, the scenario is similar to C4 plants, although CAM stomates work differently by staying closed during the day and open at night [28].

Most weed species studied so far are genetically and phenotypically diverse compared to the crops they invade. It has been repeatedly demonstrated that high genetic diversity is critical in ensuring plant survival in rapidly changing environments [3,9]. In particular, weeds' genetic diversity may produce a diversity of growth and reproductive responses to elevated $\mathrm{CO}_{2}$. Kochia is a $\mathrm{C} 4$ plant that 
often infests $\mathrm{C} 3$ crops (e.g., rice, oats, wheat). Although $\mathrm{C} 3$ crops may respond more positively to elevated $\mathrm{CO}_{2}$ when compared to kochia, the final outcome will depend on other climate factors such as precipitation [29].

A further consequence of increased $\mathrm{CO}_{2}$ is the potential for increasing glyphosate tolerance in some weed species. This shift in glyphosate tolerance due to increased $\mathrm{CO}_{2}$ has been shown to be especially profound in $\mathrm{C} 3$ weed species, but has also been demonstrated to a lesser extent in C4 plants such as kochia [30-33]. The physiological reasons for this shift in glyphosate tolerance seem to be multifaceted and are due to biochemical, physiological, and morphological properties [33].

\subsection{Precipitation and Photosynthetic Efficiency}

While variations in temperature and $\mathrm{CO}_{2}$ concentration are relatively easy to forecast, changes in precipitation patterns, intensities, and distributions are more uncertain [34]. Precipitation in the US is predicted to become more erratic, with the majority of the total rainfall occurring in May and June, and less during the growing season when it is most critical [35]. The link between water use efficiency and $\mathrm{CO}_{2}$ fixation means that drought conditions during the growing season can have a profound effect on primary productivity [36,37].

Similar to many of its relatives in the Chenopodiaceae, kochia is quite drought tolerant-requiring only $15 \mathrm{~cm}$ of annual rainfall—and can grow in highly alkaline soils [10]. Furthermore, as a C4 plant, kochia is predicted to have an advantage over $\mathrm{C} 3$ weeds or crops under drought conditions. $\mathrm{C} 4$ plants separate the light-capturing and carbon-capturing reactions in time and space, allowing light harvesting during the day and gas exchange at night [38]. However, C3 plants perform both the light-capturing and carbon-capturing reactions simultaneously, which necessitates gas exchange via stomata opening during the hottest time of the day, and limits their growth when under drought stress. Drought conditions resulting from climate change should therefore affect kochia less profoundly than its crop competitors. However, the combination of elevated $\mathrm{CO}_{2}$ concentrations and reduced precipitation may reduce the overall effect, as plant response to drought is intrinsically coupled with $\mathrm{CO}_{2}$ concentration [39].

Kochia range expansion may be dramatically affected by precipitation. For example, a $20 \%$ increase in precipitation is projected to limit the eastward expansion of kochia from the Western United States, even with a temperature rise of $1-3{ }^{\circ} \mathrm{C}$ [21]. In contrast, a $20 \%$ decrease in precipitation is projected to amplify with the effect that rising temperature will have on kochia's range by making the climate of the western part of the midwest similar to the high-plains of Colorado and Wyoming.

\section{Herbicide Resistance in Kochia}

Herbicide control of kochia has used only a few modes of action, and therefore the selection pressure for resistance to these compounds has been high. Kochia populations with resistance to photosystem II (PSII) inhibitors, acetolactate synthase (ALS) inhibitors, synthetic auxins, and glyphosate have been identified. The first case of kochia resistance to a herbicide was to atrazine (a PSII inhibitor) in 1976 [40]. Since then, intensive herbicide application to control kochia has led to increasing numbers of herbicide-resistant kochia populations reported across much of North America [41]. Even worse, a kochia population has been found with multiple resistance to all four herbicide modes of action listed above [42].

In kochia, herbicide resistance mechanisms to PSII inhibitors, ALS inhibitors, and glyphosate have been shown to be target-site-based, either from mutation (single nucleotide polymorphisms or insertion/deletions) or duplication of target-site genes [42-47]. Resistance to glyphosate arises from tandem duplication of the target-site gene [43]. For resistance to PSII inhibitors, the mutations Gly-264-Ser [42,48,49] and Val-219-Ile [49] have been found in the $p s b A$ gene. For resistance to ALS inhibitors, mutations at site Pro-197 [42,50,51], Asp-376 [51], Trp-574-Leu [42,48,51], and combinations (Pro-197 + Asp-376, or Pro-197 + Trp-574) have been reported in the ALS gene [51,52]. 
Despite auxinic herbicides being some of the first mass-produced herbicidal compounds, resistance to auxinic herbicides has been slower to evolve than for the other modes of action; however, resistance to 2,4-D, dicamba, and fluroxypyr are becoming more common [53,54]. Both target-site and non-target-site (reduced translocation) resistance mechanisms confer auxinic resistance in kochia [55,56]. A glycine to asparagine amino acid change within a highly conserved region of KsIAA16, an AUX/indole-3-acetic acid (IAA) protein, was shown to endow resistance to dicamba, with possible cross-resistance to 2,4-D and fluroxypyr [56]. Additionally, constitutively increased chalcone synthase expression in a resistant population may be related to reduced dicamba translocation, and therefore aid in resistance [55].

As climate change is predicted to favor the expansion of weed species such as kochia, there will be a greater need for methods to control them. However, the abundance of resistance mechanisms currently evolved in kochia populations, as well as a lack of new herbicide chemistries, suggests that herbicides alone will not be a long-term control strategy [57-60]. The combination of climate change and prevalent herbicide resistance alleles may result in very few options for effective control of kochia by the end of the 21st century if new, alternative control technologies are not developed.

\section{Herbicide Resistance, Fitness, and Adaptive Potential}

When hypothesizing about the interaction of herbicide resistance and climate change, another key aspect to consider is the impact of pleotropic phenotypes associated with certain resistance mutations. Usually these phenotypes are detrimental to the plant and result in a fitness penalty compared to susceptible counterparts. In general, anything that changes an organism's ability to successfully reproduce is considered a fitness penalty. In weeds, fitness is often measured in terms of seed characteristics such as seed yield, weight, germination, and dormancy [61]. These traits are all profoundly impacted by environmental conditions [6], and climate change is likely to amplify these impacts.

For example, a kochia population resistant to dicamba/fluroxypyr was found to be less competitive than susceptible kochia, with reduced germination dynamics, vegetative growth and seed production [62]. On the other hand, fitness penalties may also be ambiguous, as in the case of glyphosate-resistant kochia. Glyphosate-resistant kochia populations from Western Kansas, Western Canada and Midwestern US showed reduced seed longevity and slower rate of germination than glyphosate-susceptible populations $[63,64]$. However, glyphosate-resistant kochia populations collected from Northern Montana showed either delayed and reduced germination or no differences when compared to susceptible populations, even under a broad experimental temperature range [65]. Delayed and reduced germination characteristics of glyphosate-resistant kochia populations may offer options for weed seedbank management by altering pre-emergence herbicide timing, tillage timing, or other cultural control practices. Herbicide resistance has also been associated with increased fitness: seeds of a kochia population resistant to ALS inhibitors germinated faster and at a higher frequency than the susceptible population [66,67], showing possible benefits from resistance.

Effects of herbicide resistance on fitness have been studied under current environmental conditions, but how these pleiotropic phenotypes will manifest under a hotter and dryer regime is still unknown. Increasing competitiveness of kochia due to climate change may mitigate the mild or moderate fitness penalties arising from herbicide resistance pleiotropic phenotypes and allow strongly penalizing mutations (such as the KsIAA16 dicamba resistance mutation [68]) to persist in the population for longer.

\section{Genomics and Genetic Diversity of Kochia}

Recently, the first draft of the Kochia scoparia genome was published, with a second, reference-quality assembly in progress [46]. Similar to the genomes of fellow chenopods quinoa and sugar beet, the kochia genome has large amounts of heterozygosity, repetitive content, and transposable element activity, which has made full assembly of this weedy genome difficult $[69,70]$. However, studying these genomic features may be the key to understanding kochia's success in terms of abiotic stress tolerance and rapid resistance evolution. 
The story of glyphosate resistance evolution in kochia provides key evidence about the role of novel genetic diversity in shaping the evolutionary trajectory of a weed population. Glyphosate resistance in kochia is caused by tandem duplication of the target gene, 5-enolpyruvylshikimate-3-phosphate synthase (EPSPS) [43,45]. The tandem duplication involves the insertion of a series of mobile genetic elements flanking the EPSPS locus [46]. EPSPS is co-duplicated with several other genes whose phenotypic impact remains unknown. The novel EPSPS copy number variant (CNV) and subsequent glyphosate-resistant phenotype has led to extreme selective pressure on resistant individuals and this resistant allele. Due to the heavy selection pressure of glyphosate application, the low fitness penalty EPSPS CNV seems to incur, and the reproductive abilities of kochia, the EPSPS CNV can be quickly spread to fixation within a small kochia population. Furthermore, genes linked with the EPSPS CNV will also increase in frequency and the overall population structure altered significantly [47,71].

Structural rearrangements and changes in epigenetics can provide a huge advantage to species that need to adapt to rapidly changing environments [72,73]. Unlike the single nucleotide polymorphism mutation rate, which is determined primarily by genome size, structural rearrangements such as gene duplication occur at varying rates, where populations undergo periods of activity and dormancy [74,75]. Furthermore, many different abiotic stresses have been found to accelerate both transposable element activity and copy number variation [76-79]. Structural variation does not affect the coding sequence or the regulatory elements of a gene, which may help avoid many of the pleiotropic effects often associated with single nucleotide polymorphisms. Structural variants, such as all mutations, are predicted to usually cause a fitness penalty and therefore should be suppressed. However, kochia is an R-selected species, producing many offspring, and rare beneficial mutations can therefore manifest in the large offspring pool and spread; in turn, these successful mutants may also perpetuate a relaxed suppression of structural variant generation [64,71].

\section{Kochia Population Expansion}

Kochia is diverse in both genotype and phenotype, even in North America, where it has only had since the late 1800s (a relatively short period of time) to adapt [10]. It has been estimated that plants within populations are as genetically similar as those between populations, indicating that strongly isolated populations probably do not exist and gene flow occurs over a broad geographic range [80]. Several reproductive traits may be influencing kochia's genetic variability. First, kochia's flowers are protogynous: stigmas emerge first, receive pollen, and dehisce before the flower's own pollen production occurs. This largely prevents self-fertilization, which only occurs when no other plants are available for out-crossing [81,82]. Second, kochia is a tumbleweed, which makes its rapid dispersal very likely, especially across its current range, the windy great plains of North America [41,83].

In addition to geographical range shifts via migration, climate change will modify the size of the niche that kochia can inhabit, which will lead to changes in overall weed community composition [7]. Niches will be modified by extreme weather events predicted to become more common under future climate scenarios. Niche gaps will result from these disturbances and are potential hot spots for weedy plant invasion [84]. Once species migrate to a new location, purifying natural selection will occur, leading to local adaptation. It is often the case that species with high amounts of genetic diversity, such as kochia, quickly establish themselves in the new environment after migrations occur [9]. These evolutionary processes are categorized as trait shifts and encompass shifts in weed phenology and physiology [7].

Temperature and precipitation will be the largest abiotic factors that determine how kochia's invaded range changes in the coming decades $[85,86]$. Under increased temperatures, weed species experience shifts in geographical locations, resulting in the invasion of species into new locations as well as localized extinctions [85]. Furthermore, under predicted climate change scenarios, growing degree days will accumulate faster, resulting in weed species reaching maturity earlier in the growing season [87]. Taking into consideration kochia's ability to survive and thrive in a variety of temperature 
regimes and kochia's past history of northward invasion, it stands to reason that it will continue to move northward, invading an even larger proportion of Canadian land.

Increased moisture stress will also greatly impact weed species diversity, competition, and interactions with crops [86]. However, how a particular species distribution responds to drought is a multifactorial problem involving the weed species itself and the agroecosystem [85]. For example, in extended drought conditions, weed communities would shift to favor more deep-rooted species, whereas early emerging species, which are often shallow rooted and depend on resources in the upper soil profile, will be suppressed [88]. Drought conditions can also favor weed seed survival in the soil as dry soil conditions promote seed longevity and reduce predation $[5,89]$. Kochia thrives in arid and semi-arid climates, and if these climes expand, kochia's distribution will expand as well.

\section{Conclusions}

Global climate change will challenge all plant species; however, weedy species are especially well suited to meeting the challenge. The plethora of adaptive traits that make weeds competitive with crops (despite our best attempts to control them) overlap with traits that may help them overcome climate change. Weed populations are large and can have incredible genetic diversity on which evolution can act during this period of rapid climate change. Furthermore, as non-weed species are forced to migrate or go extinct due to climate change, ecosystems will be destabilized, and more resources will become available. Weeds can expand to fill open ecological niches and capitalize on these perturbances, similar to how they fill open niches when agricultural fields are disturbed.

Kochia scoparia is no exception to these predictions and may in fact epitomize what is to come. It has a battery of abiotic stress resilience traits, a large population size and geographic distribution, high levels of genetic diversity, and the ability to spread novel alleles over great distances. Researchers have already documented kochia's northward spread deeper into Canada due to the addition of four growing degree days, and this range expansion is unlikely to stop anytime soon, especially as we lose the ability to chemically control kochia with common herbicides due to herbicide resistance evolution. Understanding the traits that allow weeds such as kochia to be successful may be one of our greatest tools for controlling weeds. Predicting how climate change will impact weed population expansion will be essential to prepare for the future.

Author Contributions: Conceptualization, J.C., E.B., and E.P.; writing-original draft preparation, J.C., E.B., M.F., and E.P.; writing-review and editing, J.C., E.B., M.F., and E.P. All authors have read and agreed to the published version of the manuscript.

Funding: This research received no external funding.

Acknowledgments: Todd Gaines for his insights and expert knowledge of kochia.

Conflicts of Interest: The authors declare no conflict of interest.

\section{References}

1. Hatfield, J.L.; Boote, K.J.; Kimball, B.A.; Ziska, L.H.; Izaurralde, R.C.; Ort, D.; Thomson, A.M.; Wolfe, D. Climate Impacts on Agriculture: Implications for Crop Production. Agron. J. 2011, 103, 351-370. [CrossRef]

2. Thuiller, W.; Lavorel, S.; Araújo, M.B.; Sykes, M.T.; Prentice, I.C. Climate Change Threats to Plant Diversity in Europe. Proc. Natl. Acad. Sci. USA 2005, 102, 8245-8250. [CrossRef] [PubMed]

3. van Boheemen, L.A.; Atwater, D.Z.; Hodgins, K.A. Rapid and Repeated Local Adaptation to Climate in an Invasive Plant. New Phytol. 2019, 222, 614-627. [CrossRef] [PubMed]

4. Mccallum, K.P.; Guerin, G.R.; Breed, M.F.; Lowe, A.J. Combining Population Genetics, Species Distribution Modelling and Field Assessments to Understand a Species Vulnerability to Climate Change. Austral Ecol. 2014, 39, 17-28. [CrossRef]

5. Korres, N.E.; Norsworthy, J.K.; Tehranchian, P.; Gitsopoulos, T.K.; Loka, D.A.; Oosterhuis, D.M.; Gealy, D.R.; Moss, S.R.; Burgos, N.R.; Miller, M.R.; et al. Cultivars to Face Climate Change Effects on Crops and Weeds: A Review. Agron. Sustain. Dev. 2016, 36, 12. [CrossRef] 
6. Kathiresan, R.; Gualbert, G. Impact of Climate Change on the Invasive Traits of Weeds. Weed Biol. Manag. 2016, 16, 59-66. [CrossRef]

7. Peters, K.; Breitsameter, L.; Gerowitt, B. Impact of Climate Change on Weeds in Agriculture: A Review. Agron. Sustain. Dev. 2014, 34, 707-721. [CrossRef]

8. Baker, H.G. Characteristics and Modes of Origin of Weeds. In The Genetics of Colonizing Species; Academic Press: Cambridge, UK, 1965; pp. 147-172.

9. Clements, D.R.; Ditommaso, A. Climate Change and Weed Adaptation: Can Evolution of Invasive Plants Lead to Greater Range Expansion than Forecasted? Weed Res. 2011, 51, 227-240. [CrossRef]

10. Friesen, L.F.; Beckie, H.J.; Warwick, S.I.; Van Acker, R.C. The Biology of Canadian Weeds. 138. Kochia Scoparia (1.) Schrad. Can. J. Plant Sci. 2009, 89, 141-167. [CrossRef]

11. Mesbah, A.; Miller, S.D.; Fornstrom, K.J.; Legg, D.E. Kochia (Kochia scoparia) and Green Foxtail (Setaria viridis) Interference in Sugarbeets (Beta vulgaris). Weed Technol. 1994, 8, 754-759. [CrossRef]

12. Schweizer, E.E. Predicting Sugarbeet Root Losses Based on Kochia Densities. Weed Sci. 1973, 21, 565-567. [CrossRef]

13. Waite, J.; Thompson, C.R.; Peterson, D.E.; Currie, R.S.; Olson, B.L.S.; Stahlman, P.W.; Al-Khatib, K. Differential Kochia (Kochia scoparia) Populations Response to Glyphosate. Weed Sci. 2013, 61, 193-200. [CrossRef]

14. Wicks, G.A.; Martin, A.R.; Haack, A.E.; Mahnken, G.W. Control of Triazine-Resistant Kochia (Kochia scoparia) in Sorghum (Sorghum bicolor). Weed Technol. 1994, 8, 748-753. [CrossRef]

15. Wicks, G.A.; Martin, A.R.; Mahnken, G.W. Control of Triazine-Resistant Kochia (Kochia scoparia) in Conservation Tillage Corn (Zea Mays). Weed Sci. 1993, 41, 225-231. [CrossRef]

16. Collins, M.; Knutti, R.; Arblaster, J.; Dufresne, J.L.; Fichefet, T.; Friedlingstein, P.; Gao, X.; Gutowski, W.J.; Johns, T.; Krinner, G.; et al. Long-Term Climate Change: Projections, Commitments and Irreversibility. In Climate Change 2013 the Physical Science Basis: Working Group I Contribution to the Fifth Assessment Report of the Intergovernmental Panel on Climate Change; Cambridge University Press: Cambridge, UK, 2013; pp. 1029-1136. [CrossRef]

17. Hatfield,J.L.; Prueger, J.H. Temperature Extremes: Effect on Plant Growth and Development. Weather Clim. Extrem. 2015, 10, 4-10. [CrossRef]

18. Kucharik, C.J. Contribution of Planting Date Trends to Increased Maize Yields in the Central United States. Agron. J. 2008, 100, 328-336. [CrossRef]

19. Schwartz-Lazaro, L.M.; Copes, J.T. A Review of the Soil Seedbank from a Weed Scientists Perspective. Agronomy 2019, 9, 369. [CrossRef]

20. Kumar, V.; Jha, P.; Dille, J.A.; Stahlman, P.W. Emergence Dynamics of Kochia (Kochia scoparia) Populations from the U.S. Great Plains: A Multi-Site-Year Study. Weed Sci. 2018, 66, 25-35. [CrossRef]

21. Beckie, H.J.; Weiss, R.M.; Leeson, J.Y.; Olfert, O.O. Range Expansion of Kochia (Kochia scoparia) in North America under a Changing Climate. In Topics in Canadian Weed Science; Canadian Weed Science Society: Pinawa, MB, Canada, 2012; Volume 8, pp. 31-44. [CrossRef]

22. Ball, M.C.; Harris-Pascal, D.; Egerton, J.J.G.; Lenné, T. The Paradoxical Increase in Freezing Injury in a Warming Climate: Frost as a Driver of Change in Cold Climate Vegetation. In Temperature Adaptation in a Changing Climate: Nature at Risk; CABI: Cambridge, UK, 2011; pp. 179-185. [CrossRef]

23. Toderich, K.; Black, C.; Juylova, E.; Kozan, O.; Tolib, M.; Matsuo, N. Climate Change and Terrestrial Carbon Sequestration in Central Asia; CRC Press: Boca Raton, FL, USA, 2007; pp. 33-63.

24. Lüthi, D.; Le Floch, M.; Bereiter, B.; Blunier, T.; Barnola, J.M.; Siegenthaler, U.; Raynaud, D.; Jouzel, J.; Fischer, H.; Kawamura, K.; et al. High-Resolution Carbon Dioxide Concentration Record 650,000-800,000 Years before Present. Nature 2008, 453, 379-382. [CrossRef]

25. Barnaby, J.Y.; Ziska, L.H. Plant Responses to Elevated $\mathrm{CO}_{2}$; John Wiley \& Sons, Ltd.: Hoboken, NJ, USA, 2012; pp. 1-10. [CrossRef]

26. Ainsworth, E.A.; Rogers, A. The Response of Photosynthesis and Stomatal Conductance to Rising $\left[\mathrm{CO}_{2}\right]$ : Mechanisms and Environmental Interactions. Plant Cell Environ. 2007, 30, 258-270. [CrossRef]

27. Gray, S.B.; Brady, S.M. Plant Developmental Responses to Climate Change. Dev. Biol. 2016, 419, 64-77. [CrossRef]

28. Forseth, I. The Ecology of Photosynthetic Pathways. Nat. Educ. Knowl. 2010, 3, 4.

29. Freitag, H.; Kadereit, G. $\mathrm{C}_{3}$ and $\mathrm{C}_{4}$ Leaf Anatomy Types in Camphorosmeae (Camphorosmoideae, Chenopodiaceae). Plant Syst. Evol. 2014, 300, 665-687. [CrossRef] 
30. Matzrafi, M.; Brunharo, C.; Tehranchian, P.; Hanson, B.D.; Jasieniuk, M. Increased Temperatures and Elevated $\mathrm{CO}_{2}$ Levels Reduce the Sensitivity of Conyza Canadensis and Chenopodium Album to Glyphosate. Sci. Rep. 2019, 9, 1-11. [CrossRef] [PubMed]

31. Matzrafi, M.; Seiwert, B.; Reemtsma, T.; Rubin, B.; Peleg, Z. Climate Change Increases the Risk of Herbicide-Resistant Weeds Due to Enhanced Detoxification. Planta 2016, 244, 1217-1227. [CrossRef]

32. Ziska, L.H.; Teasdale, J.R.; Bunce, J.A. Future Atmospheric Carbon Dioxide May Increase Tolerance to Glyphosate. Weed Sci. 1999, 47, 608-615. [CrossRef]

33. Fernando, N.; Manalil, S.; Florentine, S.K.; Chauhan, B.S.; Seneweera, S. Glyphosate Resistance of $C_{3}$ and $C_{4}$ Weeds under Rising Atmospheric $\mathrm{CO}_{2}$. Front. Plant Sci. 2016, 7, 910. [CrossRef]

34. Varanasi, A.; Prasad, P.V.V.; Jugulam, M. Impact of Climate Change Factors on Weeds and Herbicide Efficacy. Adv. Agron. 2016, 135, 107-146. [CrossRef]

35. Dai, S.; Shulski, M.D.; Hubbard, K.G.; Takle, E.S. A Spatiotemporal Analysis of Midwest US Temperature and Precipitation Trends during the Growing Season from 1980 to 2013. Int. J. Climatol. 2016, 36, 517-525. [CrossRef]

36. Medrano, H.; Escalona, J.M.; Bota, J.; Gulías, J.; Flexas, J. Regulation of Photosynthesis of $C_{3}$ Plants in Response to Progressive Drought: Stomatal Conductance as a Reference Parameter. Ann. Bot. 2002, 89, 895-905. [CrossRef]

37. Leakey, A.D.B.; Ferguson, J.N.; Pignon, C.P.; Wu, A.; Jin, Z.; Hammer, G.L.; Lobell, D.B. Water Use Efficiency as a Constraint and Target for Improving the Resilience and Productivity of $\mathrm{C}_{3}$ and $\mathrm{C}_{4}$ Crops. Annu. Rev. Plant Biol. 2019, 70, 781-808. [CrossRef]

38. Ehleringer, J.R.; Cerling, T.E. $\mathrm{C}_{3}$ and $\mathrm{C}_{4}$ Photosynthesis. Encycl. Glob. Environ. Chang. 2002, 2, 186-190.

39. Patterson, D.T. Responses of Soybean (Glycine max) and Three $\mathrm{C}_{4}$ Grass Weeds to $\mathrm{CO}_{2}$ Enrichment During Drought. Weed Sci. 1986, 34, 203-210. [CrossRef]

40. Heap, I. The International Herbicide-Resistant Weed Databas. Available online: http://www.weedscience. org/Home.aspx (accessed on 16 September 2020).

41. Kumar, V.; Jha, P.; Jugulam, M.; Yadav, R.; Stahlman, P.W. Herbicide-Resistant Kochia (Bassia scoparia) in North America: A Review. Weed Sci. 2019, 67, 4-15. [CrossRef]

42. Varanasi, V.K.; Godar, A.S.; Currie, R.S.; Dille, A.J.; Thompson, C.R.; Stahlman, P.W.; Jugulam, M. Field-Evolved Resistance to Four Modes of Action of Herbicides in a Single Kochia (Kochia Scoparia L. Schrad.) Population. Pest Manag. Sci. 2015, 71, 1207-1212. [CrossRef] [PubMed]

43. Jugulam, M.; Niehues, K.; Godar, A.S.; Koo, D.H.; Danilova, T.; Friebe, B.; Sehgal, S.; Varanasi, V.K.; Wiersma, A.; Westra, P.; et al. Tandem Amplification of a Chromosomal Segment Harboring 5-Enolpyruvylshikimate-3-Phosphate Synthase Locus Confers Glyphosate Resistance in Kochia Scoparia. Plant Physiol. 2014, 166, 1200-1207. [CrossRef]

44. Gaines, T.A.; Barker, A.L.; Patterson, E.L.; Westra, P.; Westra, E.P.; Wilson, R.G.; Jha, P.; Kumar, V.; Kniss, A.R. EPSPS Gene Copy Number and Whole-Plant Glyphosate Resistance Level in Kochia Scoparia. PLoS ONE 2016, 11, e0168295. [CrossRef]

45. Wiersma, A.T.; Gaines, T.A.; Preston, C.; Hamilton, J.P.; Giacomini, D.; Robin Buell, C.; Leach, J.E.; Westra, P. Gene Amplification of 5-Enol-Pyruvylshikimate-3-Phosphate Synthase in Glyphosate-Resistant Kochia Scoparia. Planta 2015, 241, 463-474. [CrossRef]

46. Patterson, E.L.; Saski, C.A.; Sloan, D.B.; Tranel, P.J.; Westra, P.; Gaines, T.A. The Draft Genome of Kochia Scoparia and the Mechanism of Glyphosate Resistance via Transposon-Mediated EPSPS Tandem Gene Duplication. Genome Biol. Evol. 2019, 11, 2927-2940. [CrossRef]

47. Patterson, E.L.; Pettinga, D.J.; Ravet, K.; Neve, P.; Gaines, T.A. Glyphosate Resistance and EPSPS Gene Duplication: Convergent Evolution in Multiple Plant Species. J. Hered. 2018, 109, 117-125. [CrossRef]

48. Foes, M.J.; Liu, L.; Vigue, G.; Stoller, E.W.; Wax, L.M.; Tranel, P.J. A Kochia (Kochia scoparia) Biotype Resistant to Triazine and ALS-Inhibiting Herbicides. Weed Sci. 1999, 47, 20-27. [CrossRef]

49. Mengistu, L.W.; Christoffers, M.J.; Lym, R.G. A PsbA Mutation in Kochia Scoparia (L) Schrad from Railroad Rights-of-Way with Resistance to Diuron, Tebuthiuron and Metribuzin. Pest Manag. Sci. 2005, 61, 1035-1042. [CrossRef]

50. Kumar, V.; Jha, P.; Giacomini, D.; Westra, E.P.; Westra, P. Molecular Basis of Evolved Resistance to Glyphosate and Acetolactate Synthase-Inhibitor Herbicides in Kochia (Kochia scoparia) Accessions from Montana. Weed Sci. 2015, 63, 758-769. [CrossRef] 
51. Warwick, S.I.; Xu, R.; Sauder, C.; Beckie, H.J. Acetolactate Synthase Target-Site Mutations and Single Nucleotide Polymorphism Genotyping in ALS-Resistant Kochia (Kochia scoparia). Weed Sci. 2008, 56, 797-806. [CrossRef]

52. Guttieri, M.J.; Eberlein, C.V.; Thill, D.C. Diverse Mutations in the Acetolactate Synthase Gene Confer Chlorsulfuron Resistance in Kochia (Kochia scoparia) Biotypes. Weed Sci. 1995, 43, 175-178. [CrossRef]

53. Preston, C.; Belles, D.S.; Westra, P.H.; Nissen, S.J.; Ward, S.M. Inheritance of Resistance to The Auxinic Herbicide Dicamba in Kochia (Kochia scoparia). Weed Sci. 2009, 57, 43-47. [CrossRef]

54. Westra, E.P.; Nissen, S.J.; Getts, T.J.; Westra, P.; Gaines, T.A. Survey Reveals Frequency of Multiple Resistance to Glyphosate and Dicamba in Kochia (Bassia scoparia). Weed Technol. 2019, 33, 664-672. [CrossRef]

55. Pettinga, D.J.; Ou, J.; Patterson, E.L.; Jugulam, M.; Westra, P.; Gaines, T.A. Increased Chalcone Synthase (CHS) Expression Is Associated with Dicamba Resistance in Kochia Scoparia. Pest Manag. Sci. 2018, 74, 2306-2315. [CrossRef]

56. LeClere, S.; Wu, C.; Westra, P.; Sammons, R.D. Cross-Resistance to Dicamba, 2,4-D, and Fluroxypyr in Kochia Scoparia Is Endowed by a Mutation in an AUX/IAA Gene. Proc. Natl. Acad. Sci. USA 2018, 115, E2911-E2920. [CrossRef] [PubMed]

57. Dayan, F.E. Current Status and Future Prospects in Herbicide Discovery. Plants 2019, 8, 341. [CrossRef]

58. Duke, S.O. Why Have No New Herbicide Modes of Action Appeared in Recent Years? Pest Manag. Sci. 2012, 68, 505-512. [CrossRef]

59. Heap, I. Herbicide Resistant Weeds. In Integrated Pest Management: Pesticide Problems; Springer: Dordrecht, The Netherland, 2014; Volume 3, pp. 281-302. [CrossRef]

60. Busi, R.; Vila-Aiub, M.M.; Beckie, H.J.; Gaines, T.A.; Goggin, D.E.; Kaundun, S.S.; Lacoste, M.; Neve, P.; Nissen, S.J.; Norsworthy, J.K.; et al. Herbicide-Resistant Weeds: From Research and Knowledge to Future Needs. Evol. Appl. 2013, 6, 1218-1221. [CrossRef]

61. Vila-Aiub, M.M. Fitness of Herbicide-Resistant Weeds: Current Knowledge and Implications for Management. Plants 2019, 8, 469. [CrossRef]

62. Kumar, V.; Jha, P. Differences in Germination, Growth, and Fecundity Characteristics of Dicamba-Fluroxypyr-Resistant and Susceptible Kochia Scoparia. PLoS ONE 2016, 11, e0161533. [CrossRef]

63. Beckie, H.J.; Blackshaw, R.E.; Leeson, J.Y.; Stahlman, P.W.; Gaines, T.A.; Johnson, E.N. Seedbank Persistence, Germination and Early Growth of Glyphosate-Resistant Kochia Scoparia. Weed Res. 2018, 58, 177-187. [CrossRef]

64. Osipitan, O.A.; Dille, J.A. Fitness Outcomes Related to Glyphosate Resistance in Kochia (Kochia scoparia): What Life History Stage to Examine? Front. Plant Sci. 2017, 8, 1090. [CrossRef]

65. Kumar, V.; Jha, P. Effect of Temperature on Germination Characteristics of Glyphosate-Resistant and Glyphosate-Susceptible Kochia (Kochia scoparia). Weed Sci. 2017, 65, 361-370. [CrossRef]

66. Dyer, W.E.; Chee, P.W.; Fay, P.K. Rapid Germination of Sulfonylurea-Resistant Kochia Scoparia L. Accessions Is Associated with Elevated Seed Levels of Branched Chain Amino Acids. Weed Sci. 1993, 41, 18-22. [CrossRef]

67. Thompson, C.R.; Thill, D.C.; Shafii, B. Growth and Competitiveness of Sulfonylurea-Resistant and-Susceptible Kochia (Kochia scoparia). Weed Sci. 1994, 42, 172-179. [CrossRef]

68. Wu, C.; LeClere, S.; Liu, K.; Paciorek, M.; Perez-Jones, A.; Westra, P.; Sammons, R.D. A Dicamba Resistance-Endowing IAA16 Mutation Leads to Significant Vegetative Growth Defects and Impaired Competitiveness in Kochia (Bassia scoparia)t. Pest Manag. Sci. 2020, 1-10. [CrossRef]

69. Jarvis, D.E.; Ho, Y.S.; Lightfoot, D.J.; Schmöckel, S.M.; Li, B.; Borm, T.J.A.; Ohyanagi, H.; Mineta, K.; Michell, C.T.; Saber, N.; et al. The Genome of Chenopodium Quinoa. Nature 2017, 542, 307-312. [CrossRef]

70. Rodríguez del Río, Á.; Minoche, A.E.; Zwickl, N.F.; Friedrich, A.; Liedtke, S.; Schmidt, T.; Himmelbauer, H.; Dohm, J.C. Genomes of the Wild Beets Beta Patula and Beta Vulgaris Ssp. Maritima. Plant J. 2019, 99, 1242-1253. [CrossRef]

71. Gaines, T.A.; Patterson, E.L.; Neve, P. Molecular Mechanisms of Adaptive Evolution Revealed by Global Selection for Glyphosate Resistance. New Phytol. 2019, 223, 1770-1775. [CrossRef]

72. Kovalchuk, I.; Kovalchuk, O. Genome Stability: From Virus to Human Application; Academic Press: Cambridge, UK, 2016.

73. Franks, S.J.; Hoffmann, A.A. Genetics of Climate Change Adaptation. Annu. Rev. Genet. 2012, 46, 185-208. [CrossRef] 
74. De Maagd, R.A.; Van De Wiel, C.; Schouten, H.J. The Plasticity of Plant Genomes Causes and Consequences: A Survey of Data on Structural Genome Variation in Plants; Wageningen Plant Research: Wageningen, The Netherlands, 2020.

75. Lynch, M. Evolution of the Mutation Rate. Trends Genet. 2010, 26, 345-352. [CrossRef]

76. Migicovsky, Z.; Kovalchuk, I. Transgenerational Inheritance of Epigenetic Response to Cold in Arabidopsis Thaliana. Biocatal. Agric. Biotechnol. 2015, 4, 1-10. [CrossRef]

77. Migicovsky, Z.; Yao, Y.; Kovalchuk, I. Transgenerational Phenotypic and Epigenetic Changes in Response to Heat Stress in Arabidopsis Thaliana. Plant Signal. Behav. 2014, 9, e27971. [CrossRef]

78. Reza Rahavi, S.M.; Kovalchuk, I. Transgenerational Changes in Arabidopsis Thaliana in Response to UV-C, Heat and Cold. Biocatal. Agric. Biotechnol. 2013, 2, 226-233. [CrossRef]

79. Debolt, S. Copy Number Variation Shapes Genome Diversity in Arabidopsis over Immediate Family Generational Scales. Genome Biol. Evol. 2010, 2, 441-453. [CrossRef]

80. Mengistu, L.W.; Messersmith, C.G. Genetic Diversity of Kochia. Weed Sci. 2002, 50, 498-503. [CrossRef]

81. Guttieri, M.J.; Eberlein, C.V.; Souza, E.J. Inbreeding Coefficients of Field Populations of Kochia Scoparia Using Chlorsulfuron Resistance as a Phenotypic Marker. Weed Sci. 1998, 46, 521-525. [CrossRef]

82. Stallings, G.P.; Thill, D.C.; Mallory-Smith, C.A.; Shafii, B. Pollen-Mediated Gene Flow of Sulfonylurea-Resistant Kochia (Kochia scoparia). Weed Sci. 1995, 43, 95-102. [CrossRef]

83. Baker, D.V.; Beck, K.G.; Bienkiewicz, B.J.; Bjostad, L.B. Forces Necessary to Initiate Dispersal for Three Tumbleweeds. Invasive Plant Sci. Manag. 2008, 1, 59-65. [CrossRef]

84. Hobbs, R.J.; Huenneke, L.F. Disturbance, Diversity, and Invasion: Implications for Conservation. Conserv. Biol. 1992, 6, 324-337. [CrossRef]

85. Amare, T. Review on Impact of Climate Change on Weed and Their Management. Am. J. Biol. Environ. Stat. 2016, 2, 21-27. [CrossRef]

86. Ramesh, K.; Matloob, A.; Aslam, F.; Florentine, S.K.; Chauhan, B.S. Weeds in a Changing Climate: Vulnerabilities, Consequences, and Implications for Future Weed Management. Front. Plant Sci. 2017, 8, 95. [CrossRef]

87. Singh, R.P.; Singh, R.K.; Singh, M.K. Impact of Climate and Carbon Dioxide Change on Weeds and Their Management-A Review. Indian J. Weed Sci. 2011, 43, 1-11.

88. Sheley, R.L.; Svejcar, T.J.; Maxwell, B.D. A Theoretical Framework for Developing Successional Weed Management Strategies on Rangeland. Weed Technol. 1996, 10, 766-773. [CrossRef]

89. Zinsmeister, J.; Leprince, O.; Buitink, J. Molecular and Environmental Factors Regulating Seed Longevity. Biochem. J. 2020, 447, 305-323. [CrossRef]

Publisher's Note: MDPI stays neutral with regard to jurisdictional claims in published maps and institutional affiliations.

(C) 2020 by the authors. Licensee MDPI, Basel, Switzerland. This article is an open access article distributed under the terms and conditions of the Creative Commons Attribution (CC BY) license (http://creativecommons.org/licenses/by/4.0/). 